\title{
PENGEMBANGAN MEDIA PEMBELAJARAN INTERAKTIF BERBASIS PROBLEM BASED LEARNING PADA PEMBELAJARAN TEMATIK
}

\author{
Kartini Tambunan ${ }^{1}$, Harun Sitompul ${ }^{2}$, R. Mursid ${ }^{3}$ \\ ${ }^{1}$ SD Swasta Islam An-Nizam Medan Denai, ${ }^{2,3}$ Pascasarjana Universitas Negeri Medan \\ kartini@gmail.com ${ }^{1}$; profharun@unimed.ac.id ${ }^{2}$; mursid.tp@gmail.com ${ }^{3}$
}

\begin{abstract}
Abstrak: Tujuan penelitian ini untuk mengetahui kelayakan media pembelajaran interaktif berbasis problem based learning yang dipergunakan pada pembelajaran tematik di SD Swasta Islam An-Nizam Kecamatan Medan Denai dan mengetahui keefektifan penggunaan media interaktif berbasis problem based learning pada pembelajaran tematik di SD Swasta Islam An-Nizam Kecamatan Medan Denai. Adapun subjek dari penelitian ini adalah siswa kelas V SD Swasta Islam An-Nizam yang berjumlah 25 orang. Sebagai objek dalam penelitian ini adalah media pembelajaran, skala respon siswa terhadap media pembelajaran dan tes hasil belajar siswa. Model pengembangan yang akan digunakan untuk mengembangkan perangkat media pembelajaran dalam penelitian ini adalah model Thiagarajan yang dikenal dengan Four-D (Model 4-D). Model 4-D diplih karena sistematis dan sesuai untuk mengembangkan perangkat pembelajaran. Hasil penelitian yaitu media interaktif berbasis problem based learning yang dipergunakan pada pembelajaran tematik di SD Swasta Islam An-Nizam Kecamatan Medan Denai layak digunakan. Media interaktif berbasis problem based learning pada pembelajaran tematik di SD Swasta Islam An-Nizam Kecamatan Medan Denai efektif digunakan.
\end{abstract}

Kata Kunci : Pengembangan Video Pembelajaran, Hasil Belajar Matematika

\begin{abstract}
Absract: The purpose of this study is to determine the feasibility of interactive learning media based on problem based learning which is used in thematic learning at SD Swasta Islam An-Nizam Medan Denai and to know the effectiveness of the use of interactive media based on problem based learning on thematic learning at SD Swasta Islam An-Nizam Medan Denai. The subject of this research is the students of class $V$ SD Swasta Islam An-Nizam Medan Denai which amounted to 25 people. As object in this research is media of learning, scale of student response to instructional media and test result of student learning. The development model that will be used to develop learning media device in this research is Thiagarajan model known as Four-D (Model 4-D). The 4-D model is compiled because it is systematic and appropriate for developing learning tools. The result of the research is interactive media based on problem based learning which is used in thematic learning at An-Nizam Private Islamic Elementary School of Medan Denai District. Interactive media based on problem based learning on thematic learning at SD Swasta Islam An-Nizam Medan Denai District effectively used.
\end{abstract}

Keywords: Development, Interactive Media and Problem Based Learning

\section{PENDAHULUAN}

Keberhasilan peningkatan mutu sumber daya manusia melalui pendidikan tiak dapat dipisahkan dari kemampuan guru dalam mendesain suatu proses pembelajaran sehingga siswa memperoleh keterampilan dan nilai yang nencukupi standar nasional. Hal ini tentu didukung oleh kemampuan guru dalam mengajar. Hamalik (2008:44) mengemukakan bahwa mengajar dapat diartikan sebagai (1) menyampaikan pengetahuan kepada siswa, (2) mewariskan kebudayaan kepada generasi muda, (3) usaha mengorganisasi lingkungan sehingga menciptakan kondisi belajar bagi siswa, (4) memberikan bimbingan kepada siswa, (5) kegiatan mempersiapkan siswa untuk menjadi warga negara yang baik, (6) suatu proses membantu siswa menghadapi kehidupan seharihari.

Dalam pelaksanaan pembelajaran guru dituntut untuk dapat menggunakan media maupun menerapkan model pembelajaran yang tepat sehingga hasil yang dicapai lebih maksimal. Salah satu media tersebut seperti media interaktif dan juga penggunaan model pembelajaran yang sesuai dengan pembelajaran tematik seperti penggunaan model pembelajaran problem based learning dimana terjadi pengubahan pembelajaran yang melibatkan siswa dengan segala nuansanya, juga menyertakan segala ikatan, interaksi dan perbedaan yang memaksimalkan momen belajar. 
Salah satu cara untuk mendapat hasil belajar yang baik adalah merubah paradigma pembelajaran dari model pembelajaran ceramah ke arah model yang sesuai untuk mewakili kebutuhan dalam pembelajaran. Oleh sebab itu, sudah saatnya guru mulai mengalihkan perhatian pada model pembelajaran. Dalam pandangan ini para guru merencanakan dan melaksanakan inovasi altenatif pembelajaran sehingga siswa tidak hanya belajar verbal yang bersifat monoton, tetapi juga memiliki keterampilan-keterampilan untuk memecahkan masalah yang ditemukan dalam kehidupan sehari-hari. Juga dapat membantu siswa dalam melaksanakan tugas belajar yang berorientasi kepada siswa.

Keberhasilan pelaksanaan pembelajaran di dukung oleh pembuatan dan penggunaan media yang tepat. Pengembangan media diantaranya adalah pada media pembelajaran interaktif dengan menggunakan model pembelajaran problem based learning yang disesuaikan dengan kebutuhan siswa SD Swasta Islam AnNizam Kecamatan Medan Denai. Pembelajaran problem based learning adalah upaya mengajar untuk mengubah suasana belajar yang monoton dan membosankan menjadi suasana belajar yang mengaktifkan siswa dengan memadukan potensi fisik, psikis dan emosi siswa menjadi suatu kesatuan kekuatan yang integral. Model pembelajaran problem based learning berisi prinsip-prinsip sistem perancangan pengajaran yang efektif, efisien dan progesif dengan penyajiannya untuk mendapat hasil belajar yang lebih baik.

Menurut Lehman (2008:117) bahwa media pembelajaran adalah segala sesuatu yang dapat membawa pesan untuk pencapaian tujuan pembelajaran. Penggunaan media pembelajaran tentunya adalah upaya mempermudah komunikasi dan mendukung terhadap pencapaian hasil belajar siswa. Menurut Joyce (2009:119) bahwa media pembelajaran meliputi alat yang secara fisik digunakan untuk menyampaikan isi materi pelajaran yang terdiri dari buku, tape recorder, kaset, video, video recorder, film, slide (gambar bingkai), photo, gambar, grafik, televisi dan computer. Dengan kata lain media dalah komponen sumber belajar atau wahana fisik yang mengandung materi instruksional di lingkungan siswa yang mampu untuk merangsang aktivitas belajar siswa.

$$
\begin{gathered}
\text { Selanjutnya } \quad \text { Winkel } \\
\text { mengemukakan bahwa media } \\
\text { pembelajaran }
\end{gathered}
$$

diartikan sebagai suatu sarana non personal (bukan manusia) yang digunakan atau disediakan oleh pengajar, yang memegang peranan penting dalam proses belajar mengajar untuk mencapai tujuan instruksional. Menurut Sanjaya (2008:108) bahwa media pembelajaran adalah seluruh alat dan bahan yang dapat dipakai untuk mencapai tujuan pendidikan seperti radio, televisi, buku, koran, majalah, dan sebagainya.

Dengan demikian pemilihan dan penggunaan media yang tepat guna akan menambah efektivitas proses pembelajaran yang dilaksanakan, karena pemilihan media yang tepat tentu akan memberikan perhatian menarik sehingga dapat menimbulkan rasa ingin tahu yang tinggi bagi siswa dan hal ini akan mempermudah terjadinya proses pembelajaran itu sendiri di dalam kelas.

Menurut Arsyad (2011:117) bahwa media memiliki 4 fungsi yaitu fungsi atensi, fungsi afektif, fungsi kognitif, dan fungsi kompensatoris. Dalam fungsi atensi media dapat menarik dan mengarahkan siswa untuk berkonsentrasi kepada isi pelajaran. Fungsi afektif dari media dapat diamati dan tingkat kenikmatan siswa ketika belajar (membaca) teks bergambar. Dalam hal ini gambar atau simbol visual dapat menggugah emosi dan sikap siswa.

Menurut Arsyad (2011: 164) bahwa sejalan dengan perkembangan teknologi, maka media pembelajaran mengalami perkembangan melalui pemanfaatan teknologi itu sendiri. Berdasarkan perkembangan teknologi, media diklasifikasikan atas empat kelompok yaitu : (1) media hasil teknologi cetak, (2) media hasil teknologi audio-visual, (3) media hasil teknologi berbasis komputer, dan (4) media hasil gabungan teknologi cetak dan komputer.

$$
\text { Selanjutnya Mursid (2013:125) }
$$
mengemukakan bahwa pengembangan pembelajaran adalah aktivitas atau proses yang sistematis dalam upaya menghasilkan suatu program pembelajaran untuk mencapai tujuan tertentu. Proses sistematis karena memiliki komponen-komponen aktivitas yang dipadukan sedemikian rupa secara prosedural. Prosedur sistematis tersebut adalah sebagai suatu perancangan pembelajaran yang di dalamnya memuat tahap-tahap pengembangan.

Seels \& Galsgow dalam (Arsyad, 2011:36) mengemukakan bahwa media pembelajaran interaktif adalah suatu sistem penyampaian 
pengajaran yang menyajikan materi video rekaman dengan pengendalian komputer kepada siswa yang tidak hanya mendengar dan melihat video dan suara tetapi juga memberikan respon aktif dan respon itu yang menentukan kecepatan dan skuensi penyajian.

Media interaktif adalah sebagai sarana penyaji materi yang akan disampaikan. Media interaktif adalah media yang digunakan pada proses pembelajaran sebagai penyalur pesan sehingga memungkankan terjadinya interaksi. Selanjutnya Supriyadi (2012:8) mengemukakan salah satu contoh media interaktif adalah game dan gambar bergerak. Sedangkan pembelajaran diartikan sebagai proses penciptaan lingkungan yang memungkinkan terjadinya proses belajar.

Sagala (2009:175) menyatakan model dapat dipahami sebagai suatu tipe atau desain, deskripsi atau analogi, suatu system asumsiasumsi, suatu desain yang sederhana dari suatu sistem kerja, suatu deskripsi dari suatu sistem yang mungkin atau imajiner, dan penyajian yang diperkecil agar dapat menjelaskan dan menunjukkan sifat bentuk aslinya.

Trianto (2009:61) mengemukakan bahwa pengajaran berdasarkan masalah merupakan pendekatan yang efektif untuk pengajaran proses berpikir tingkat tinggi. Pembelajaran ini membantu siswa untuk memperoleh informasi yang sudah jadi dalam benaknya dan menyusun pengetahuan mereka sendiri tentang dunia sosial dan sekitarnya. Pembelajaran ini cocok untuk mengembangkan pengetahuan dasar maupun kompleks.

Trianto (2009:70) menegaskan bahwa model pembelajaran berbasis masalah dikembangkan terutama untuk membantu siswa mengembangkan kemampuan berpikir, pemecahan masalah, dan keterampilan intelektual, belajar tentang berbagai peran orang dewasa melalui kelibatan mereka pengalaman nyata atau simulasi, dan menjadi pembelajaran yang otonom dan mandiri.

Taufiq Amir (2009:32) mengemukakan keunggulan dan kelemahan model pembelajaran probem based learning sebagai berikut:

a) Keunggulan Model Pembelajaran Probem

\section{Based Learning}

Sebagai suatu model pembelajaran, model pembelajaran probem based learning memiliki beberapa keunggulan, di antaranya:

1) Model pembelajaran probem based learning merupakan tehknik yang cukup bagus untuk lebih memahami isi pelajaran.
2) Dapat menantang kemampuan siswa serta memberikan kepuasan untuk menemukan pengetahuan baru bagi siswa.

3) Dapat meningkatkan aktivitas pembelajaran siswa.

4) Dapat membantu siswa bagaimana mentransfer pengetahuan mereka untuk memahami masalah dalam kehidupan nyata.

5) Dapat membantu siswa mengembangkan pengetahuan barunya dan bertanggung jawab dalam penbelajaran yang mereka lakukan. Disamping itu, model probem based learning juga dapat mendorong untuk dapat melakukan evaluasi sendiri baik terhadap hasil maupun hasil belajarnya.

6) Melalui model probem based learning bisa memperlihatkan kepada siswa bahwa setiap mata pelajaran merupakan cara berpikir dan sesuatu yang dimengerti oleh siswa, bukan hanya sekedar belajar dari guru atau dari buku-buku saja.

7) Dianggap lebih menyenangkan dan disukai siswa.

8) Dapat mengembangkan kemampuan siswa untuk berpikir kritis dan mengembangkan kemampuan mereka untuk menyesuaikan dengan kemampuan baru.

9) Dapat memberikan kesempatan kepada siswa untuk mengaplikasikan pengetahuan mereka dalam dunia nyata.

10) Dapat mengembangkan minat siswa untuk secara terus menerus belajar sekalipun belajar pada pendidikan formal terakhir.

b) Kelemahan Model Pembelajaran Probem Based Learning

Disamping keunggulan, model probem based learning juga memiliki kelemahan yaitu:

1) Manakala siswa tidak memiliki minat atau tidak mempunyai kepercayaan bahwa masalah yang dipelajari sulit untuk dipecahkan, maka mereka akan merasa enggan untuk mencoba.

2) Keberhasilan model pembelajaran ini membutuhkan cukup waktu untuk persiapan.

3) Tanpa pemahaman mengapa mereka berusaha untuk memecahkan masalah yang sedang dipelajari, maka mereka tidak akan belajar apa yang ingin mereka pelajari. 
Dimyati dan Mudjiono (2008:297) mengemukakan bahwa pembelajaran adalah kegiatan guru secara terprogram dalam desain instruksional, untuk membuat siswa belajar secara aktif yang menekankan pada penyediaan sumber belajar. Ciri-ciri pembelajaran adalah mendukung proses belajar siswa, adanya interaksi antara individu dengan sumber belajar yang memiliki komponen-komponen tujuan, materi, proses dan evaluasi yang saling berkaitan.

Mardianto (2011:121) mengemukakan bahwa pembelajaran tematik dapat dilakukan dengan baik apabila diperhatikan rambu rambu berikut bahwa : (1) semua mata pelajaran jangan dipaksakan untuk disatukan atau dipadukan dalam satu tema, (2) dalam menganalisis kompetensi dasar dapat saja terjadi lintas antar semester, (3) apabila kompetensi dasar tidak dapat dipadukan dalam tema sebaiknya dikembangkan tema lain, apabila tidak dapat juga maka dikembangkan tema berdasarkan kompetensi dasar tersebut, dan (4) dalam pembelajaran tematik untuk kelas awal diingatkan bahwa penekanan utama adalah untuk meningkatkan kemampuan membaca, menulis, berhitung dan mengembangkan sikap positif terhadap arti kehidupan.

\section{METODE PENELITIAN}

\section{Tempat dan Waktu Penelitian}

Lokasi penelitian adalah di SD Swasta Islam An-Nizam Jl. Tuba Nomor 62 Kecamatan Medan Denai. Penelitian dilaksanakan pada siswa kelas V SD Swasta Islam An-Nizam Kecamatan Medan Denai. Penelitian dilakukan pada semester genap

\section{Subjek dan Objek Penelitian}

Adapun subjek dari penelitian ini adalah siswa SD Swasta Islam An-Nizam yang terdiri dari kelas $\mathrm{V}$ sebagai kelas yang diberi pembelajaran menggunakan media interaktif berbasis problem based learning. Sebagai objek dalam penelitian ini adalah media pembelajaran, skala respon siswa terhadap media pembelajaran dan tes hasil belajar siswa

\section{Model Pengembangan}

Model pengembangan yang akan digunakan untuk mengembangkan perangkat media pembelajaran dalam penelitian ini adalah model Thiagarajan yang dikenal dengan Four$D$ (Model 4-D). Model 4-D diplih karena sistematis dan sesuai untuk mengembangkan perangkat pembelajaran. Reynolds dalam Rochmad (2012:61) mengemukakan bahwa model Four-D tersebut dalam dijadikan sumber ide dan prosedur pengembangan untuk mengembangkan perangkat media pembelajaran dan penyebarannya (dissemination) pada bidang lain.

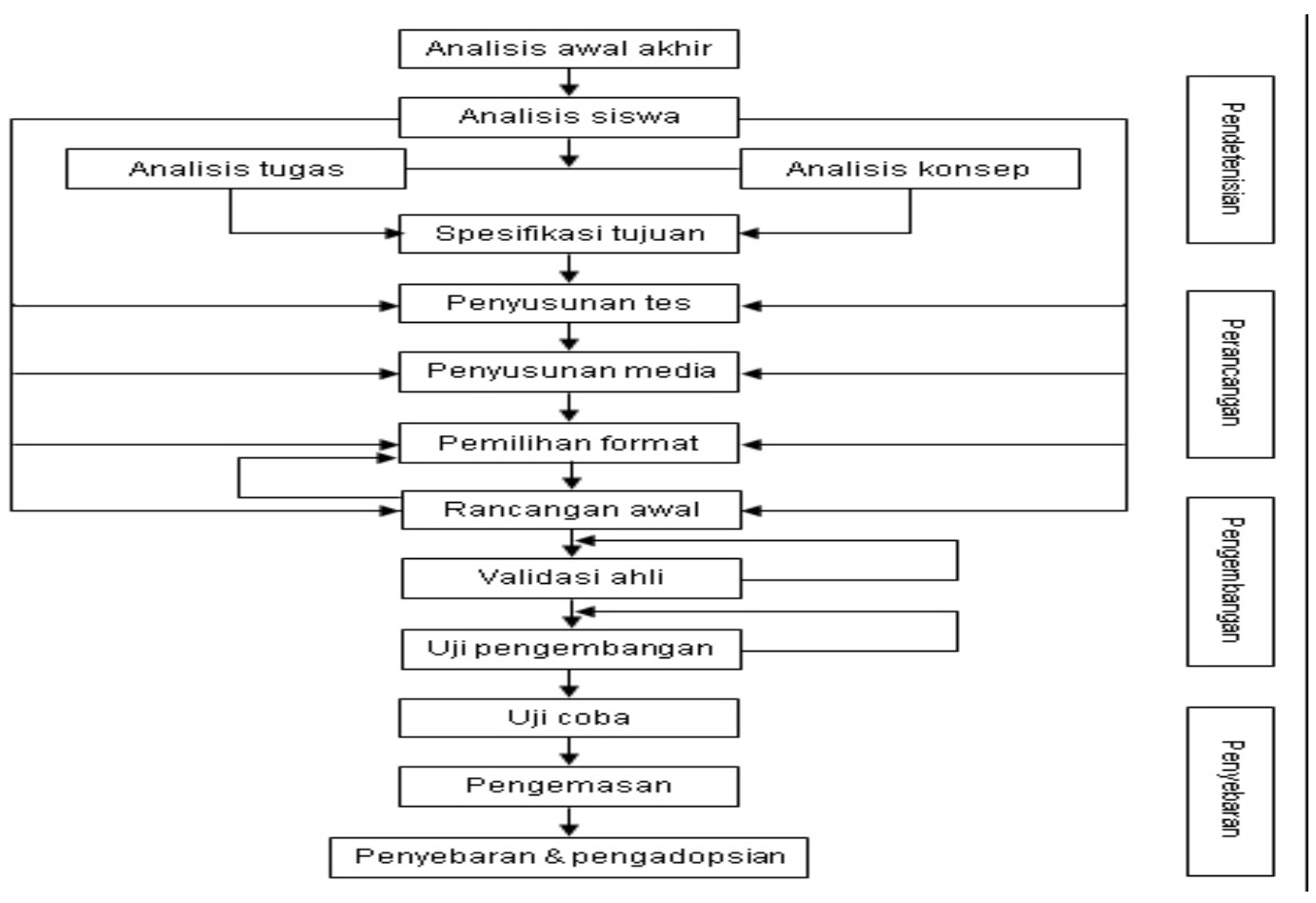

Gambar 1. Model Pengembangan 


\section{Instrumen Penelitian}

Instrumen pengumpulan data yang digunakan dalam penelitian pengembangan media interaktif pembelajaran adalah berupa instrumen penialaian produk yang dikembangkan. Adapun instrumen yang digunakan untuk untuk mengumpulkan data yang dibutuhkan dalam penelitian ini terdiri dari :

(1) Lembar Angke

(2) Instrumen yang digunakan dalam penelitian ini adalah : (a) lembar angket untuk ahli materi, (2) lembar angket untuk ahli desain pembelajaran, (3) lembar angket untuk ahli perangkat lunak, (4) lembar angket untuk peserta didik.

a. Tes Hasil Belajar

Tes digunakan untuk mengetahui pemahaman dan penguasaan siswa terhadap materi pelajaran yaitu tentang bangun datar dengan penggunaan media video pembelajaran berbasis masalah. Tes yang diberikan dalam berbentuk essay test terhadap pemahaman, penguasaan materi, keakuratan melakukan penyelesaian soal. Tes dilakukan sebelum pembelajaran dan sesudah pelaksanaan pembelajaran di kelas.

\section{Teknik Analisis Data}

Analisis data dalam penelitian ini menggunakan analisis deskriptif kuantitaif. Sugiyono (2009:118) mengemukakan bahwa teknik deskriptif adalah statistik yang digunakan untuk menganalisis data dengan cara menggambarkan data yang telah terkumpul sebagaimana adanya tanpa bermaksud membuat kesimpulan yang berlaku untuk umum atau generalisasi.

Data yang diperoleh dari lapangan penelitian selanjutnya dilakukan analisis data. Teknik analisis data dengan menggunakan tahapan analisis sesuai jenis data dan tujuan pelaksanaan pengembangan media video pembelajaran. Teknik analisis data dapat dikemukakan sebagai berikut:

Selanjutnya untuk perhitungan tingkat kelayakan pada media video pembelajaran penilaian adalah dengan pedoman berikut:

Tabel 1. Persentase Kriteria Tingkat Kelayakan

\begin{tabular}{cll}
\hline Nilai & Tingkat Kelayakan & Skor \\
\hline 1 & Tidak Layak & $<65 \%$ \\
\hline 2 & Kurang Layak & $65 \%-74 \%$ \\
\hline 3 & Layak & $75 \%-84 \%$ \\
\hline 4 & Sangat Layak & $85 \%-100 \%$ \\
\hline
\end{tabular}

Untuk menganalisis keefektifan produk yaitu dari data perbandingan rata-rata hasil belajar kelas PBL dan kelas Ekspositori dengan menggunaka Independent Samples Test Program SPSS 20. Dengan nilai $t_{\text {hitung }}>t_{\text {tabel }}$ dan sig.2-tailed $(0,005)<\alpha=0,05$ sehingga maka Ho di tolak.

\section{HASIL DAN PEMBAHASAN Hasil Validasi Ahli}

Pengujian kelayakan produk yang dikembangkan dianalisis dari validasi kelayakan dari ahli dan kelayakan uji coba kepada siswa. Hasil uji coba validasi kelayakan ahli dan uji coba kelayakan

Hasil validasi yang dilakukan oleh ahli materi terhadap media video pembelajaran berbasis masalah materi bangun datar dapat dikemukakan sebagai berikut :

Tabel 2. Rangkuman Penilaian Ahli Materi Terhadap Media

\begin{tabular}{lccc}
\hline No & Aspek Penilaian & Persentase & Kriteria \\
\hline 1. & Materi Pembelajaran & $95,03 \%$ & Sangat Baik \\
\hline 2. & Desain Pembelajaran & $83,53 \%$ & Baik \\
\hline 3. & Media pembelajaran & $82,97 \%$ & Baik \\
\hline Persentase & $95,00 \%$ & Sangat Baik \\
\hline
\end{tabular}

Berdasarkan Tabel 4.30 di atas dapat dikemukakan kesimpulan bahwa produk media interaktif berbasis problem based learning yang dikembangkan termasuk kriteria sangat baik yang berarti bahwa sangat layak digunakan dan dapat memenuhi kebutuhan pelaksanaan pembelajaran tematik. 
Tabel 3. Rangkuman hasil ujicoba lapangan

\begin{tabular}{clcl}
\hline No & Aspek Penilaian & Persentase & Kriteria \\
\hline 1. & Tampilan & 86,13 & Sangat Baik \\
\hline 2. & Penyajian & 85,94 & Sangat Baik \\
\hline 3. & Manfaat & 87,47 & Sangat Baik \\
\hline & Rata-Rata & $86,51 \%$ & Sangat Baik \\
\hline
\end{tabular}

Berdasarkan Tabela 4.31 di atas dapat diketahui bahwa penilaian media pembelajaran interaktif berbasis problem based learning uji coba lapangan dapat dikemukakan kesimpulan bahwa hasil media interaktif yang dikembangkan termasuk kriteria sangat baik. Berdasarkan hasil uji validasi kelayakan oleh ahli dan dan uji lapangan yang dilakukan kepada siswa membuktikan bahwa produk media interaktif berbasis problem based leaning yang dikembangkan termasuk kriteriaa sangat baik yang berabrti bahwa media interaktif yang dikembangkan adalah sangat layak digunakan dalam pelaksanaan pembelajaran tematik khususnya pada siswa SD.

Hasil uji hipotesis keefektifan produk diketahui melalui perbedaan pretes dan postes hasil belajar siswa kelas problem based learning dan kelas ekspositori yaitu:

1) Kedua data pretes hasil belajar siswa mempunyai nilai $\mathrm{t}_{\text {hitung }}(0,097)<\mathrm{t}_{\text {tabel }}(1,671)$ dan sig.2-tailed $(0,923)>\alpha=0,05$ sehingga $\mathrm{H}_{0}$ diterima dan Ha ditolak. Berdasarkan hasil perhitungan tersebut dapat dikemukakan kesimpulan bahwa kedua kelas memiliki rata-rata pretes hasil belajar yang sama.

2) Kedua data postes hasil belajar siswa mempunyai nilai $t_{\text {hitung }}(2,967)>t_{\text {tabel }}(1,671)$ dan sig.2-tailed $(0,005)<\alpha=0,05$ sehingga $\mathrm{H}_{0}$ ditolak dan Ha diterima. Berdasarkan hasil perhitungan tersebut dapat dikemukakan kesimpulan bahwa kedua kelas memiliki rata-rata pretes hasil belajar yang berbeda.

\section{PEMBAHASAN}

Berdasarkan hasil uji validasi ahli terhadap media video pembelajaran berbasis masalah yang dikembangkan dapat diketahui rata-rata persentase penilain ahli materi sebesar $95,00 \%$ dengan kategori sangat baik, rata-rata penilaian ahli desain instruksional sebesar 91,49\% dengan kategori sangat baik, rata-rata penilaian ahli media pembelajaran sebesar 85,36 dengan ketagori sangat baik. Keseluruhan rata-rata penilaian ahli sebesar 90,62\% dengan kategori persentase kriteria kesesuaian indikator sangat baik digunakan dan valid untuk digunakan.

Seorang guru dapat memotivasi siswanya agar dapat membangkitkan minat belajarnya dengan cara memberikan dan menimbulkan harapan. Harapan akan tercapainya suatu hasrat atau tujuan dapat menjadi motivasi yang ditimbulkan guru kedalam diri siswa. Salah satu pemberian harapan itu yakni dengan cara memudahkan siswa dalam menerima dan memahami isi pelajaran yakni melalui pemanfaatan media pembelajaran yang tepat guna

Penggunaan media berperan dalam pelaksanaan pembelajaran, diantaranya adalah untuk menarik perhatian peserta didik sehingga dapat menimbulkan motivasi belajar dan memungkinkan peserta didik menguasai tujuan pembelajaran lebih baik. Selain itu metode mengajar akan lebih bervariasi, tidak sematamata komunikasi verbal melalui penuturan kata-kata oleh guru, sehingga peserta didik tidak bosan dan guru juga tidak kehabisan tenaga apalagi bila guru mengajar setiap jam pelajaran. Peran media dalam pembelajaran selanjutnya adalah membuat peserta didik lebih banyak melakukan kegiatan belajar, dan aktivitas lainnya seperti mengamati, melakukan, mendemonstrasikan, dan sebagainya.

Hasil analisis data pretes dan postes hasil belajar siswa sebelum dan sesudah menggunakan media interaktif berbasis problem based learning dapat dikemukakan bahwa skor rata-rata hasil belajar sebesar 55,00 dan setelah menggunakan media interaktif berbasis problem based learning sebesar 84,24 dengan ketuntasan klasikal sebesar $100 \%$. Selanjutnya keefektifan penggunaan media interaktif yang dikembangkan dapat dibuktikan dari perbedaan postes hasil belajar siswa pada kelas problem based learning rata-rata postes sebesar 82,24 sedangkan pada kelas ekspositori sebesar 78,96. Hasil ini membuktikan bahwa adanya keefektifan penggunaan media interaktif berbasis problem based learning yang dikembangkan. 
Seiring dengan perkembangan teknologi, telah banyak dikembangkan media pembelajaran yang menggunakan perangkat komputer. Pembelajaran dengan komputer dapat menyajikan media pembelajaran yang memuat materi pembelajaran secara tekstual, audio maupun visual secara menarik. Hal ini juga didukung dengan perkembangan teknologi komputer terutama dalam bidang perangkat lunak yang semakin pesat.

Sadiman (2012:112) mengemukakan bahwa media adalah segala sesuatu yang dapat digunakan untuk menyalurkan pesan dari pengirim ke penerima sehingga dapat merangsang pikiran, perasaan, perhatian, dan minat seta perhatian siswa sedemikian rupa sehingga proses belajar terjadi. Media pun memiliki terkait dengan perangkat lunak berisi pesan pendidikan yang biasanya disajikan dengan mempergunakan peralatan.

Kemp dan Dayton dalam Kustandi (2011:20) mengemukakan bahwa media pembelajaran dapat memenuhi tiga fungsi utama apabila media itu digunakan untuk perorangan, kelompok, atau kelompok yang besar jumlahnya, yaitu dalam hal : (1) memotivasi minat atau tindakan, (2) menyajikan informasi, dan (3) memberi instruksi. Untuk memenuhi fungsi motivasi, media pembelajaran dapat direalisasikan dengan teknik drama atau hiburan. Sedangkan untuk tujuan informasi, media pembelajaran dapat digunakan dalam rangka penyajian informasi di hadapan sekelompok siswa. Isi dan bentuk penyajian bersifat sangat umum, berfungsi sebagai pengantar, ringkasan laporan, atau pengetahuan latar belakang. Penyajian dapat pula berbentuk hiburan, drama, atau teknik motivasi.

\section{PENUTUP}

\section{Kesimpulan}

Setelah melakukan proses atau tahapan pengembangan media interaktif berbasis problem based learning dapat dikemukakan kesimpulan sebagai berikut :

1. Media interaktif berbasis problem based learning yang dipergunakan pada pembelajaran tematik di SD Swasta Islam An-Nizam Kecamatan Medan Denai layak digunakan

2. Media interaktif berbasis problem based learning pada pembelajaran tematik di SD
Swasta Islam An-Nizam Kecamatan Medan Denai efektif digunakan.

\section{DAFTAR PUSTAKA}

Ahmadi dan Supriono W. (2001). Psikologi Belajar, Jakarta : Rineka Cipta

Amir, M. Taufiq. (2009). Inovasi Pendidikan Melalui Problem Based Learning. Jakarta: Kencana Prenada Media Group

Arends, Richard. (2008). Learning to Teach. Penerjemah : Helly Prajitno dan Sri Mulyani. New York: McGraw Hill Company

Arikunto, S., (2008). Penelitian Tindakan Kelas, Penerbit Bumi Aksara, Jakarta.

Arsyad. (2011). Media Pembelajaran. Jakarta : Rajawali Pers

Badjoeadji. (2012). Pemograman Dengan Microsoft Excel 007 VBA Module E Auditor. Jakarta: Rineka Cipta.

BNSP Depdiknas. (2006). Panduan Penyusunan Kurikulum Tingkat Satuan Pendidikan. Jakarta: BNSP Depdiknas.

Buchori, Alma. (2008). Guru Profesional Menguasai Metode dan Terampil Mengajar. Bandung: Alfabeta

Dick, W. and Carey. (2005). The Systematic Design of Instrution. 4 th. Harper Colins

Dimyati, Mudjiono. (2008). Belajar dan Pembelajaran, Jakarta: Rineka Cipta.

Gardner. (2007). The Condition of Learning and Theory of Instruction. Fourth Edition. New York : Holt. Rine Hart and Winston.

Hamalik. (2008). Kurikulum dan Pembelajaran. Jakarta: Bumi Aksara

Joyce, Bruce \& Marsha Weil. (2009).Models of Teaching, New Yersey : Prentice-Hall, Inc.

Joyce. B dan weil. M. (2000). Model of Teaching, Foreword by James worlfsixth Edition Amerika.

Mardianto. (2011). Pembelajaran Tematik. Medan : Perdana Mulya Sarana

Moudhoffir. (2007). Teknologi Instruksional Sebagai Landasan Perencanaan dan Penyusunan Program Pengajaran, Bandung : Remaja Rosda Karya

Nasution. (2008). Metode Research. Bumi Aksara: Jakarta

Nur M. (2006). Model Pembelajaran Berbasis Masalah. LPMP Ditjen PMPTK Depdiknas 
Pujianto. (2000). Pemanfaatan ICT Sebagai Sumber Belajar Sains Dalam Penerapan Problem Based Learning Di sekolah. Tesis: Jakarta UNJ.

Purwodarminto. (2000). Kamus Umum Bahasa Indonesia. Jakarta: Depdiknas.

R. Mursid. (2013). Pengembangan Model Pembelajaran Berbasis Kompetensi (Suatu Pendekatan Pembelajaran Praktik Berbasis Kompetensi Berorientasi Produksi Pada Pendidikan Teknik Mesin). Medan: Unimed Pres

Rahimah. (2014). Pengembangan Media Interaktif Berbasis Strtaegi PBL Pada Mata Pelajaran Pattern Making Kelas $X$ SMK $N \quad 8$ Medan. Tesis. Medan: UNIMED.

Rahmadina. (2013). Pengembangan Multimedia Interaktif Berbasis Masalah Pada Perkuliahan Mikrobiologi Terapan Pada Prodi Pendidikan Biologi. Tesis. Medan : UNIMED

Roestiyah, N. K. (2011). Strategi Belajar Mengajar. Jakarta: Rineka Cipta.

Rozali. (2103). Landasan Psikologi Proses Pendidikan. Bandung : Remaja Rosda Karya.

Rusman. (2010). Model-Model Pembelajaran Mengembangkan Profesionalisme Guru. Jakarta: Rajawali Press

Rusmono. (2012). Strategi pembelajaran Dengan Problem Based Learning itu perlu. Bogor: Ghalia Indonesia
Sagala, Syaiful. (2009). Konsep dan Makna Pembelajaran. Bandung: Alfabeta

Sanjaya, Wina. (2008). Kurikulum dan Pembelajaran: Teori dan Praktik Pengembangan Kurikukum Tingkat Satuan Pendidikan (KTSP). Jakarta: Kencana Prenada Media Group.

Sukirman. (2012). Kinerja Pimpinan Jurusan di Perguruan Tinggi: Teori, Konsep dan Korelatnya. Yogyakarta: Laksbang Pressindo.

Sukma Pertiwi. (2014). Pengembangan Media Pembelajaran Interaktif Berbasis Blended Learning Pada Materi Kultur Jaringan Kelas XII SMA Negeri 1 Simpang Empat Asahan. Tesis. Medan: UNIMED.

Supriyadi. (2012). Internet Masuk Sekolah, Pemberdayaan Guru dan Siswa dalam Era Sekolah Berbasis E Learning. Bandung: PT. Telkom

Susilana. (2009). Media Pembelajaran. Bandung: Wacana Prima

Trianto. (2009). Model-Model Pembelajaran Inovatif Berorientasi Konstruktivistik, Penerbit Prestasi Pustaka, Jakarta.

Usman, U. (2010). Menjadi Guru Profesional. Remaja Rosdakarya, Bandung.

Van de Walle, J.A. (2008). Matematika Sekolah Dasar dan Menengah. Jakarta: Erlangga

Winkel, WS. (2008). Psikologi Pendidikan dan Evaluasi Belajar. Jakarta: Gramedia. 